\title{
Status of Small-scale Rubber and Shifting Cultivators at Bandarbans District, Bangladesh
}

\author{
A. K. M Abul Kalam Azad, Md. Najmus Sayadat Pitol, and Yonosuke Hara
}

\section{ABSTRACT}

The study explored the general overview of the small-scale rubber cultivators and shifting cultivators at Bandarbans District, Bangladesh. The living standard of small-scale rubber cultivators were higher than the shifting cultivators. The all-small-scale rubber farm households were divided into three classes rich, medium, and poor according to their present wealthy status where all shifting cultivators were unfortunately poor. The rich farm household of rubber cultivators had the highest annual income $(177857$ BDT) and shifting cultivators had an average lowest annual income (43842 BDT). In total $58 \%$ farmers had started latex collection, and $42 \%$ percent farmers were waiting to start latex. It seemed that only shifting cultivators worked as day labor and not involved in any other parttime profession. They had less livestock and agricultural land. About $48 \%$ of farmers cultivated banana as the intercrop in the rubber garden for the first few years followed by fruits $(13 \%)$, ginger $(11 \%)$, vegetables $(8 \%)$, pineapple $(8 \%)$, garlic $(6 \%)$ and rice $(6 \%)$. All the respondents $(100 \%)$ faced financial, VAT and transportation problem. About $88 \%$ respondents faced clone selection problem followed by insufficient land allocation $(85 \%)$, marketing problem $(79 \%)$, shortage of skilled manpower $(65 \%)$, latex collection $(58 \%)$, skilled tapper $(52 \%)$, diseases $(17 \%)$ and others (25\%).

Keywords: income, living standard, latex, livelihood, rubber, shifting cultivation, tree farming.

\section{INTRODUCTION}

Farming with rubber (Hevea brasiliensis) unlocks a fresh prospect to the small-scale farmers that diminishing the shifting cultivation. Nath et al. [1] stated that rubber cultivation could aid to exterminate poverty in the hilly area of Bangladesh. Where shifting cultivation is unjustifiable environmentally and economically, many countries in Asia are changing the scheme with permanent agriculture or tree farming [2]. But it is considered the foremost source of livelihood for tribal people and still being widely practiced in hilly areas of Bangladesh [2], [3]. About 26,000 households exercise shifting cultivation every year, and nearly 143,000 individuals depend on it [4]. It increases the deforestation rate through accelerating soil erosion [5]-[7] that affect soil quality [7] and cause land degradation. The fallow period for shifting cultivation has been reduced to 3-4 years because of the rapid growth in population that agreeing very little time for soil revival [8]. During the period of heavy rainfall, it directed to the decline of faunal and microbial organisms, top soil loss, and land degradation due to slashing and burning [9].

In Bangladesh, the increasing demand for rubber and rubber products insisted on the new moneymaking plantation of rubber. From the other hand, create any plantation near and within natural forest or hill decreases the diversity of forest [10]. But still rubber plantation proved as an excellent tool to cope with the food, wood, energy, ecology, poverty crises and lessen the deforestation rate of Bangladesh.

\section{A. Study Area}

Submitted : May 18, 2021

Published : June 09, 2021

ISSN: $2684-1827$

DOI: $10.24018 /$ ejfood.2021.3.3.303

\author{
A. K. M. Abul Kalam Azad \\ Bangladesh Planning Commission, \\ Ministry of Planning, Agargoan, Dhaka. \\ National Graduate Institute for Policy \\ Studies (GRIPS), Tokyo, Japan. \\ (e-mail: akmakazad@ gmail.com) \\ Md. Najmus Sayadat Pitol ${ }^{*}$ \\ Mangrove Silviculture Division, \\ Bangladesh Forest Research Institute, \\ Ministry of Environment, Forest and \\ climate change, Bangladesh. \\ (e-mail: najmus.sayadat@ gmail.com) \\ Yonosuke Hara \\ National Graduate Institute for Policy \\ Studies (GRIPS), Tokyo, Japan. \\ (e-mail: yhara@ grips.ac.jp)
}

*Corresponding Author

forest lands in Bangladesh. Rubber (Hevea brasiliensis) is one of the cash crops that is the source of natural latex and also used in furniture industries [11], [12]. Large-scale rubber plantations were established in the central and eastern hilly parts of Bangladesh [13]. At present, both the governmental and private sectors 18,954 ha plantation of $H$. brasiliensis has been developed and planned to expand its further 1214 ha during 2020 [14], [15]. It was seemed that the plantations forest stored a huge amount of carbon from the environment [16], [17]. The leaves of rubber trees are used as fodder, seeds are the ingredient in poultry feed and seed cakes [18]. Rubberwood has also used for making furniture, plywood, particleboard, chemical pulping and packing cases [19], [21]. Presently, rubber plantation meets only $30 \%$ of the total current domestic raw rubber demand [22]. The study aims to explore the suitability of rubber plantations and also gives the general overview of rubber cultivators and shifting cultivators at Bandarbans hill tract in

\section{MATERIAL AND METHODS}

Bandarban, the most remote and least dense district of Bangladesh with an area of $4,479 \mathrm{~km}^{2}$. About 2,15,934 of Bengalis and $1,42,401$ of indigenous people live in the district [23]. It lies between $22^{\circ} 11^{\prime}$ and $22^{\circ} 30^{\prime}$ north latitudes and between $92^{\circ} 04^{\prime}$ and $92^{\circ} 41^{\prime}$ east longitudes [23] (Fig. 1). There are 50.8\% Muslim, 31.7\% Buddhist, 
10.1\% Christian, 3.4\% Hindu and 4\% others [23]. There are more than fifteen ethnic minorities together with Marma, Rakhine, Mru , Bawm, Khyang, Tripura, Lushei, Khumi, Chak, Kuki, Chakma and Tanchangya. Both shifting cultivators and rubber cultivators are found in the study area where forestry, fisheries, and livestock are the main source of household income [23]. The climatic conditions are moist, warm, and equable. The average temperature is $26.10^{\circ} \mathrm{C}$, and the minimum and maximum temperatures were recorded as $10{ }^{\circ} \mathrm{C}$ in December-January and $34.8^{\circ} \mathrm{C}$ from May to March to June [23].

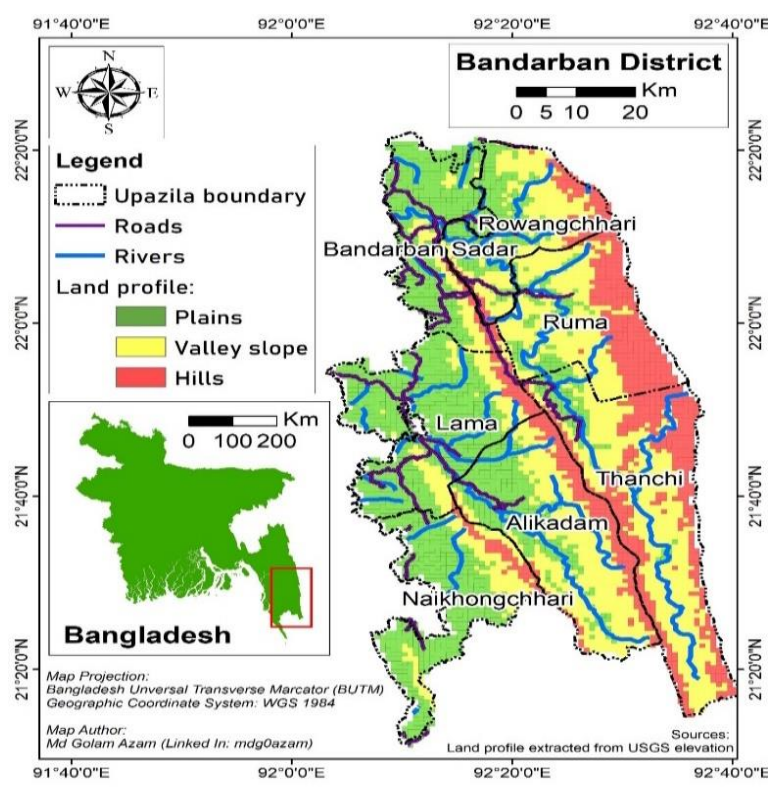

Fig. 1. Map of Bandarban District.

\section{B. Data Collection and Analysis}

To find out the general overview of the small-scale rubber cultivators and shifting cultivators, both qualitative and quantitative data on rubber production, their income, resources, and other status were used. Data was collected by group discussion, direct observation, and a questionnaire survey of the households. There were 48 registered smallscale rubber cultivators, and 38 shifting cultivators were interviewed. The focus group consultations were held with the village authorities to understand the general circumstances of the study area by information gathering on rubber and shifting cultivation. Lastly information regarding the quantity and cost of the labor force used for the rubber and shifting cultivation was collected. During the focus group discussion, several field observations were conducted with their cordial help.

\section{RESULT AND DISCUSSION}

\section{A. Small-scale Rubber Cultivator}

\section{Family Information of small-scale rubber cultivators}

All households of the village were categorized into three groups according to their wealthy status. The headman of the village and the village authorities classified this groups according to the land resources and annual income because he was responsible for collecting the tax of the tribal group of the village. The total land resource was more than 10 acres and annual income more than 100000 BDT was considered as a rich group followed by 6 to 10 acres and $60000 \mathrm{BDT}$ to $100000 \mathrm{BDT}$ was considered as medium and less than 6 acres and income less than 60000 BDT was considered as poor household. In this study, the small-scale rubber farm households showed that the average age of rich households was larger (45 years > 37 years) than the poor household (Table I). Similarly, at the education level (13.14) and average yearly income (136714 BDT) was also higher than the medium and poor household (Table I). The average household size of poor farmers was bigger $(5.05>4.57)$ than that of rich households. This situation was common in whole Bangladesh that the low-income families have more children than the wealthy and educated family.

TABLE I: FAMILY INFORMATION OF RUBBER FARM HOUSEHOLDS

\begin{tabular}{|c|c|c|c|}
\hline Variables & $\begin{array}{c}\text { Rich } \\
\text { households }\end{array}$ & $\begin{array}{l}\text { Medium } \\
\text { households }\end{array}$ & $\begin{array}{c}\text { Poor } \\
\text { households }\end{array}$ \\
\hline Number of households (\%) & $7(14 \%)$ & $22(46 \%)$ & $19(40 \%)$ \\
\hline $\begin{array}{c}\text { Average age of head of } \\
\text { household (year) }\end{array}$ & 45.14 & 42.27 & 37.79 \\
\hline $\begin{array}{l}\text { Education of head of } \\
\text { household (year) }\end{array}$ & 13.14 & 6.59 & 5.21 \\
\hline $\begin{array}{l}\text { Average household size } \\
\text { (number/household) }\end{array}$ & 4.57 & 4.82 & 5.05 \\
\hline $\begin{array}{l}\text { Average household } \\
\text { income BDT/year }\end{array}$ & 136714 & 82818 & 48105 \\
\hline
\end{tabular}

\section{Income Sources of small-scale rubber farm households}

The main occupation of the respondents was agriculture, but there were other occupations like schoolteachers, government and non-government officials, small business, fishing, and different types of non-agricultural labors. The yearly income of the households of small-scale rubber cultivators came not only from rubber cultivation but also from other sources (Table II). All kinds of rich rubber farmers had the highest average yearly income from rubber and intercrops (38\%) followed by services (25\%), business $(15 \%)$ and agriculture and others $(16 \%)$. Some head of the household also had part-time services or seasonal works. The farm households also had income from other agricultural activities such as rice, vegetables and fruits at their homesteads and agricultural land. Some farmers did not have own agricultural land, but they took the land lease from other people for one or several years and grew agricultural products. The average annual income derived from rubber farms was 47231 BDT which was providing about $50 \%$ of their total household income. The average highest income derived from rubber cultivation by a rich group of farmers followed by medium and poor group. The highest average share of income $(3.59 \%)$ also obtained from rubber cultivation by the rich group of farmers.

TABLE II: AVERAGE YEARLY INCOME OF DIFFERENT SOURCES OF SMALL-

\begin{tabular}{cccc}
\multicolumn{3}{c}{ SCALE RUBBER FARM HOUSEHOLDS } & \\
\hline $\begin{array}{c}\text { Sources of } \\
\text { income }\end{array}$ & $\begin{array}{c}\text { Rich } \\
\text { households } \\
(\mathrm{n}=7)\end{array}$ & $\begin{array}{c}\text { Medium } \\
\text { households } \\
(\mathrm{n}=22)\end{array}$ & $\begin{array}{c}\text { Poor } \\
\text { households } \\
(\mathrm{n}=19)\end{array}$ \\
\hline Rubber and & 66142.86 & 50136.36 & $27600(\mathrm{BDT})$ \\
Intercrops & $(\mathrm{BDT})$ & $(\mathrm{BDT})$ & 6722.22 \\
Livestock & 11714.29 & 2230.77 & $(\mathrm{BDT})$ \\
& $(\mathrm{BDT})$ & $(\mathrm{BDT})$ & 10583.33 \\
Business & 33142.86 & 13333.33 & $(\mathrm{BDT})$ \\
Jobs/services & $(\mathrm{BDT})$ & $(\mathrm{BDT})$ & $21600(\mathrm{BDT})$ \\
Agriculture and & $18000(\mathrm{BDT})$ & $24000(\mathrm{BDT})$ & 14842.10 \\
others & $(\mathrm{BDT})$ & 24818.18 & $(\mathrm{BDT})$ \\
\hline
\end{tabular}




\section{Land Ownership of small-scale rubber farm households}

The average total land ownership of rich small-scale rubber cultivator was 13.53 acres where the medium and poor farmers had 7.33 acres and 5.63 acres of land respectively (Table III). Most of the households of the rich group were more aged or older compared to the heads of poor households. The rich group already got income from the rubber gardens because they started rubber cultivation earlier. On the other hand, the poor farmers comparatively young and started income from rubber farming very recently. So, the age of farmers makes a difference among different group of households.

TABLE III: QUANTITY OF LAND OWNERSHIP OF DIFFERENT WEALTHY

\begin{tabular}{cccc}
\multicolumn{4}{c}{ FARM HOUSEHOLDS } \\
\hline Types of land owned & $\begin{array}{c}\text { Rich } \\
\text { households }\end{array}$ & $\begin{array}{c}\text { Medium } \\
\text { households }\end{array}$ & $\begin{array}{c}\text { Poor } \\
\text { households }\end{array}$ \\
\hline $\begin{array}{c}\text { Average rubber land } \\
\text { (acre) }\end{array}$ & 9.71 & 6.09 & 5.13 \\
$\begin{array}{c}\text { Average homestead } \\
\text { land (acre) }\end{array}$ & 0.67 & 0.30 & 0.10 \\
$\begin{array}{c}\text { Average agriculture } \\
\text { land (acre) } \\
\text { Average total land } \\
\text { resource (acre) }\end{array}$ & 3.14 & 1.03 & 0.39 \\
\hline
\end{tabular}

\section{Livestock of small-scale rubber farm households}

The rich small-scale rubber cultivators had more livestock than medium or poor farm households because the rich farmers had more money to invest in livestock, and they have more spaces on their homesteads (Table IV). The common livestock in the study area was cow, goat, chicken, duck, and pigeon.

\begin{tabular}{|c|c|c|c|}
\hline \multicolumn{4}{|c|}{ RUBBER CULTIVATORS } \\
\hline Types of livestock & Rich & Medium & Poor \\
\hline Average number of cows & 5.00 & 3.56 & 2.73 \\
\hline Average number of goats & 4.25 & 4.94 & 3.89 \\
\hline $\begin{array}{c}\text { Average number of } \\
\text { chickens }\end{array}$ & 20.86 & 14.36 & 12.79 \\
\hline Average number of ducks & 10.33 & 10.38 & 11.35 \\
\hline $\begin{array}{l}\text { Average number of } \\
\text { pigeons }\end{array}$ & 28.00 & 15.15 & 12.27 \\
\hline
\end{tabular}

\section{Intercrop Production of small-scale rubber farm households}

In the study area, small-scale farmers cultivated rubber with some agricultural crops in the initial few years of rubber plantations when the rubber plants were small (Table V). Intercrop practice is common in Malaysia, Indonesia, India, Lao PDR, and China, for smallholder or any other form of rubber cultivation. The main reasons for intercropping in rubber plantation were due to lack of plenty of lands, using the spaces between the rubber trees. Farmers reported that initial stage of plantations, rubber plants needed some shade to grow well. In that sense, banana can provide sufficient shades and protect the young rubber plants from the sunshine. Intercropping with vegetables and bananas, could earn extra benefit from the intercrops besides latex. In addition, banana was very popular among the small-scale farmers of the study area because they can sell the product very easily, and it is highly flexible whole the year. Rodrigoa [24] showed that the growth of young rubber trees was unaffected by the presence of intercrop in the first initial years. Moreover, banana intercropping helps a nonstop growth of young rubber plants and increase its return. When the rubber trees become mature, then its roots and canopy spread and, in this stage, intercrop affects the normal growth and production [25]. There was also the optimum utilization of labor as a farmer may work on both rubber and intercrops simultaneously. Another objective of intercropping with rubber cultivation was for food security, employment, and maximization of farm income. Banana, pineapple, ginger, turmeric, and rice were the preferred intercrops. Banana once grown may continue for four years periods without further input cost. Khan \& Ahmed [26] reported that banana is an excellent intercrop in rubber garden for optimum utilization of land that reduce the growth of weed and create extra farm income. In India, most of the farmers like banana as intercrop in their rubber gardens and some farmers prefer cassava (Manihot esculenta) as intercrop [27]. Few farmers cultivate pineapple as an intercrop, but it reduces soil bacteria and a significant challenge for sustainable production [28]. Ginger and turmeric cultivation as an intercrop requires digging the topsoil and heavy use of organic and compost mulches. It can be grown only for two years and accelerates soil erosion during cultivation and harvesting [29].

In this study area, banana is used as the model of intercrop because, most of the small-scale farmers (more than $48 \%$ ) are cultivating banana as intercrop in their gardens. Farmers reported that banana gives a handsome return for the first few years with a very limited management cost. About $48 \%$ of farmers cultivated banana as the intercrop in the rubber garden for the first few years followed by fruits $(13 \%)$, ginger $(11 \%)$, vegetables $(8 \%)$, pineapple $(8 \%)$, garlic $(6 \%)$ and rice $(6 \%)$ (Table V). It is important to mention that the government sets a condition during land allocation that the allocated land should be exclusively used for only rubber cultivation. As a result, the farmers were not able to cultivate other crops as intercrops to get some additional income. This condition was set to promote rubber cultivation instead of other harmful land use to protect soil erosion.

TABLE V: KINDS OF INTERCROP SMALL-SCALE FARMERS RAISING IN

\begin{tabular}{ccccc} 
& \multicolumn{3}{c}{ THEIR RUBBER GARDENS } \\
\hline \multirow{2}{*}{$\begin{array}{c}\text { Types of } \\
\text { intercrops }\end{array}$} & \multicolumn{3}{c}{$\begin{array}{c}\text { Number of Rubber Farm } \\
\text { Households }\end{array}$} \\
\cline { 2 - 4 } & Rich & Medium & Poor & \\
\hline Banana & 3 & 9 & 11 & $23(48 \%)$ \\
Fruits & 2 & 2 & 2 & $6(13 \%)$ \\
Vegetable & 1 & 3 & & $4(8 \%)$ \\
Garlic & & 3 & & $3(6 \%)$ \\
Ginger & 1 & 2 & 2 & $5(11 \%)$ \\
Pineapple & & 1 & 3 & $4(8 \%)$ \\
Rice & & 2 & 1 & $3(6 \%)$ \\
\hline
\end{tabular}

\section{Rubber Production by small-scale rubber farm households}

About $100 \%$ of farmers of rich households, started latex production followed by the medium $(64 \%)$ and poor $(37 \%)$ (Table VI). The rich category farmers started rubber cultivation earlier than the poor farmers. Their gardens had already reached at matured level for latex collection. Most of the poor farmers were new and the plantations were not 
matured enough to collect latex. In total $58 \%$ farmers had started latex collection, and $42 \%$ percent farmers were waiting to start latex when their trees become seven years to latex production.

TABLE VI: SUMMARY OF STATISTICS ON RUBBER PRODUCING HOUSEHOLDS

\begin{tabular}{|c|c|c|c|c|c|}
\hline \multirow{2}{*}{$\begin{array}{c}\text { Category of } \\
\mathrm{HH}\end{array}$} & \multirow{2}{*}{$\begin{array}{l}\text { Number } \\
\text { of Plots }\end{array}$} & \multirow{2}{*}{$\begin{array}{l}\text { Average } \\
\text { land acre }\end{array}$} & \multirow{2}{*}{$\begin{array}{l}\text { Average } \\
\text { Number } \\
\text { of trees }\end{array}$} & \multicolumn{2}{|c|}{$\begin{array}{l}\text { HH production of } \\
\text { latex }\end{array}$} \\
\hline & & & & Start & $\begin{array}{l}\text { Not } \\
\text { start }\end{array}$ \\
\hline Rich (7) & 12 & 9.71 & 1754 & $7(100 \%)$ & \\
\hline $\begin{array}{l}\text { Medium } \\
\quad(22)\end{array}$ & 25 & 6.09 & 1064 & $14(64 \%)$ & $\begin{array}{c}8 \\
(36 \%)\end{array}$ \\
\hline Poor (19) & 19 & 5.16 & 852 & $7(37 \%)$ & $\begin{array}{c}12 \\
(63 \%)\end{array}$ \\
\hline Total (48) & 56 & 6.25 & 1081 & $28(58 \%)$ & $\begin{array}{c}21 \\
(42 \%)\end{array}$ \\
\hline
\end{tabular}

NB: 1 acre $=0.404$ hectare.

\section{Marketing of Latex}

It was found that out of 48 rubber farm households, most of the farmers $(58 \%)$ sell their latex product to the middleman. About $17 \%$ farmers sold the latex through another garden (17\%), and some farmers (25\%) sold their product through agents. Finally, the raw rubber goes to the industries.

\section{B. Shifting Cultivators}

A total of 38 shifting cultivators were interviewed and found that the average age level of the shifting cultivators was very high (49.89). Their average education level was very low (1.71 class). The annual average income level was very low. Their average annual income was 43,842 BDT, which is lower than that of the lowest level of salary $(4,000$ BDT) of a government employee. The average size of household was 4.74 person per household. This result reflects that the living standard of the shifting cultivators was unpleasant. The living standard of shifting cultivators were very lower than the farmers of other area in Bangladesh [30]-[34].

\section{Yearly Income Status of Shifting Cultivators}

It was found that the shifting cultivators were not completely dependent on shifting cultivation for their livelihood. They were also involved in different sources of income. Around $36 \%$ of total income came from small types of business where $23 \%$ came from daily labor and only $14 \%$ came from shifting cultivation (Fig. 2). So, shifting cultivation was not the primary source of income for the livelihood of the poor farmers who practiced it.

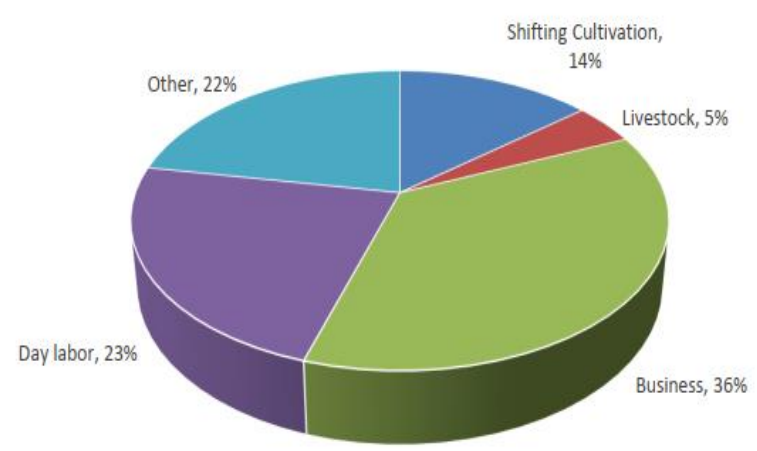

Fig. 2. Yearly income source of shifting cultivators.

\section{Comparison of small-scale rubber and shifting cultivation farm households}

The inhabitant of the study area depended on several kinds of professions. According to the headman and local authority, the all-small-scale rubber farm households were divided into three classes rich, medium, and poor according to their present wealthy status. All shifting cultivators were unfortunately poor. The rich farm household of rubber cultivators had the highest annual income (1,77,857 BDT) and shifting cultivators had an average lowest annual income (43,842 BDT). Medium and poor rubber farm households were respectively the second and third position of their income level. Poor rubber farm households were new rubber cultivators, and most of them did not start latex collection to generate revenue from rubber farms. On the other hand, rich farm households were matured rubber cultivators, and they started getting benefits from rubber garden in full swing. It seemed that only shifting cultivators worked as day labor and not involved in any other part-time profession. They had less livestock and agricultural land.

TABLE VII: SOURCES OF ANNUAL INCOME OF SMALL-SCALE RUBBER CUlTIVATORS AND SHIFTING CULTIVATORS

\begin{tabular}{|c|c|c|c|c|}
\hline \multicolumn{5}{|c|}{ CULTIVATORS AND SHIFTING CULTIVATORS } \\
\hline \multirow{2}{*}{$\begin{array}{l}\text { Sources of } \\
\text { income }\end{array}$} & \multicolumn{3}{|c|}{ Rubber Cultivators } & \multirow{2}{*}{$\begin{array}{c}\text { Shifting } \\
\text { Cultivators }\end{array}$} \\
\hline & Rich & Medium & Poor & \\
\hline $\begin{array}{l}\text { Rubber and } \\
\text { Intercrops }\end{array}$ & 66142 BDT & $50136 \mathrm{BDT}$ & $27600 \mathrm{BDT}$ & - \\
\hline $\begin{array}{c}\text { Shifting } \\
\text { Cultivation }\end{array}$ & - & - & - & 6140 BDT \\
\hline Livestock & $11714 \mathrm{BDT}$ & $2230 \mathrm{BDT}$ & 6722 BDT & $1970 \mathrm{BDT}$ \\
\hline Business & 33142 BDT & $13333 \mathrm{BDT}$ & $10583 \mathrm{BDT}$ & $15928 \mathrm{BDT}$ \\
\hline $\begin{array}{l}\text { Jobs (part- } \\
\text { time and } \\
\text { seasonal) }\end{array}$ & $48000 \mathrm{BDT}$ & $24000 \mathrm{BDT}$ & $21600 \mathrm{BDT}$ & - \\
\hline Day labor & - & - & - & $10091 \mathrm{BDT}$ \\
\hline $\begin{array}{l}\text { Agriculture } \\
\text { and others }\end{array}$ & $18857 \mathrm{BDT}$ & 24818 BDT & $14842 \mathrm{BDT}$ & $9711 \mathrm{BDT}$ \\
\hline $\begin{array}{l}\text { Total average } \\
\text { income } \\
\text { BDT/Year }\end{array}$ & $\begin{array}{c}177857 \\
\text { BDT }\end{array}$ & $\begin{array}{c}114518 \\
\text { BDT }\end{array}$ & $81347 \mathrm{BDT}$ & $43842 \mathrm{BDT}$ \\
\hline
\end{tabular}

\section{Identification the Major Problems of Small-scale Rubber Production}

The existing problems faced by the small-scale rubber cultivators of the study area were identified (Table VIII) through interview. All the respondents (100\%) faced financial, VAT and transportation problem. About $88 \%$ respondents faced clone selection problem followed by Insufficient land allocation (85\%), marketing problem (79\%), shortage of skilled manpower (65\%), latex collection $(58 \%)$, skilled tapper $(52 \%)$, diseases $(17 \%)$ and others $(25 \%)$.

TABLE VIII: IDENTIFIED PROBLEMS OF THE SMALL-SCALE RUBBER

\begin{tabular}{ccc}
\multicolumn{3}{c}{ FARMERS } \\
\hline Problems & $\begin{array}{c}\text { Number of } \\
\text { HH }\end{array}$ & $\begin{array}{c}\text { Percentage (\%) of } \\
\text { problem }\end{array}$ \\
\hline Financial Problem & 48 & $100 \%$ \\
Latex collection & 28 & $58 \%$ \\
Skilled manpower & 31 & $65 \%$ \\
Skilled tapper & 25 & $52 \%$ \\
Marketing problem & 38 & $79 \%$ \\
VAT problem & 48 & $100 \%$ \\
Insufficient land allocation & 41 & $85 \%$ \\
Road network & 48 & $100 \%$ \\
Selection of clones & 42 & $88 \%$ \\
Diseases & 8 & $17 \%$ \\
Other problems & 12 & $25 \%$ \\
\hline
\end{tabular}

Total households $=48$. 


\section{Financial Problem}

Most of the plantations and management for both nursery and plantation depended on the availability of fund or credits. The small-scale rubber farmers in the study area cultivated the rubber plantations only through their finance by way of traditional methods. They borrowed from relatives or agents because the interest rate from a private bank was very high. This means that farmers will not be able to carry out proper maintenance works such as weeding, lining, cleaning, applying fertilizer, payment for the latex collectors as they may not have adequate financial ability to do these things. They were not able to initiate any new plantation program.

\section{Latex Collection}

Highest production of rubber depends on the timely collection of the latex. The production is greater in the tapping time between 7 am to 8 am. Production progressively decreased due to late tapping and collection. The farmers did not collect the latex in proper time that was the general problem in the study area. Over-tapping of the trees in the study area was most common.

\section{Skilled Management}

Management plays an important and key element in the successful production of rubber. A good qualified and efficient manager of rubber cultivation can manage the garden efficiently. Every small-scale farmer act as a manager of his garden but he did not have any training on management of rubber garden. Most of the workers were unskilled or semiskilled in the study area.

\section{Marketing Problem}

In the study area, the small-scale rubber farmers faced problems in marketing their rubber products. They did not sell their products directly to the industries. The farmers marketed their latex yield through the middleman or local agents. Government support was lacking in this area, and the farmers did not get the proper market price of their products.

\section{Value Added Tax (VAT) Problem}

The government imposes $15 \%$ VAT on the sale of rubber yields. In case of the agro-products (such as rice, vegetables, fruits, jute) farmers were exempted from paying VAT to boost the growth of these products. However, those farmers who engaged in the rubber production not yet exempted and they demanded government support to withdrawing VAT on rubber products like as agro-products.

\section{Insufficient Land Allocation}

The government was allocating only 5 acres of fallow land to the shifting cultivators for rubber cultivation. In some cases, this allocation was increased to 25 acres for special cases. It was revealed that only those farmers with some influential and non-tribal people got these facilities. The rest were provided on only 5 acres of land allocation that was insufficient to get a good economic return.

\section{Road Network}

The road network in the study area was very bad. All of the respondents reported that the authority did not take any necessary steps to solve the problem. All internal road networks inside the village were made of mud and very narrow. During the rainy season, it was very difficult to walk on the road due to mud.

\section{CONCLUSION}

The rubber production is highly profitable than the harmful shifting cultivation. Government should provide an interest-free loan to the poor small-scale rubber cultivators that can be made more profitable. Besides, give the technical support to the shifting cultivator and encourage them that they leave the shifting cultivation and involve themselves in rubber tree farming. If the government wants to reduce shifting cultivation, must come forward with a low-interest funding for the rubber cultivators. The findings of this study about the small-scale rubber cultivators and shifting cultivators will be helpful for politicians and policy makers in framing forthcoming tactics of the tribal people, and also for sustainable highland development.

\section{ACKNOWLEDGEMENT}

Authors thank to GRIPS, Tokyo, Japan. Also thank to the staff of Bangladesh Cotton Development Board, Bandarban, Bangladesh for aiding during data collection. Special thanks to Md. Golam Azam for providing the study area map.

\section{REFERENCES}

[1] Nath, T. K., Inou, M. \& Mangala, D. Z. (2013). Small-scale rubber planting for enhancement of people's livelihoods: A comparative study in three South Asian countries, society \& natural resources. An International Journal, 26(9), 1066-1081.

[2] Rasul, G. and Thapa, G.B. (2003) Shifting cultivation in the mountains of South and Southeast Asia: Regional patterns and factors influencing the change. Land Degradation and Development 14 (5), 495-508.

[3] Khisa, S.K. (2002) Farming practices and sustainable development in the Chittagong Hill Tracts. In N.A. Khan, M.K. Alam, S.K. Khisa and M. Millate-Mustafa (eds) Farming Practices and Sustainable Development in the Chittagong Hill Tracts (pp. 49-61). Bangladesh: CHTDB and VEFP-IC.

[4] Shoaib, J.U. (2000) Development of Sustainable Cultivation Practices for Minimizing Soil Erosion on Hill Slope. Bangladesh Agricultural Research Council and Soil Resources Development Institute, Dhaka, Bangladesh.

[5] Borggaard, Ole K., Gafur, A. and Peterson, L. (2003) Sustainability appraisal of shifting cultivation in the Chittagong Hill Tracts of Bangladesh. Ambio 32 (2), 118-123. Crossref: https://doi.org/10.18801/ijbmsr.090220.55.

[6] Gafur, A., Jensen, J.R., Borggaard, O.K. and Petesen, L. (2003) Runoff and losses of soil and nutrients from small watersheds under shifting cultivation (jhum) in the Chittagong Hill Tracts of Bangladesh. Journal of Hydrology 274, 30-46.

[7] Shoaib, J.U., Mostafa, G. and Rahman, M. (1998) Soil erosion hazard in Chittagong Hill Tracts: A case study. Annual Report. Soil Resources Development Institute, Dhaka, Bangladesh.

[8] Riessen, A V (2000), "Chittagong Hill Tracts Region Development Plan”, Interim Report No.7, Sociology and Indigenous People, Asian Development Bank, Dhaka, Bangladesh.

[9] Gafur, A (2001), "Effects of shifting cultivation on soil properties, erosion, nutrient depletion, and hydrological responses in small watershed of the Chittagong Hill tracts of Bangladesh", Unpublished Ph.D. Dissertation, Chemistry Department, The Royal Veterinary and Agricultural University, Copenhagen, Denmark.

[10] Rahaman, M. T., Gurung, D. B., \& Pitol, M. N. S. (2020). Comparative Study of Understory Between Exotic Monoculture Plantation (Acacia Sp.) and Adjacent Natural Sal (Shorea Robusta) Forest. European Journal of Agriculture and Food Sciences, 2(6).

[11] Arokiaraj P, Jones H, Olsson et al. 2002. Towards Molecular Genetic Improvement of Wood and Latex Production of Hevea brasiliensis: 
Enhancement of the Carbon Sink Capacity. In: Proceeding: Fifth Joint Workshop of the Secretariat of the United Nations Conference on Trade and Development and the International Rubber Study Group on Rubber and the Environment, UK, Glasgow. International Rubber Study Group, pp. 1-9.

[12] Tissari J. 2002. Further development of the rubber wood processing industries in producer countries. In: Proceeding: Fifth Joint Workshop of the Secretariat of the United Nations Conference on Trade and Development and the International Rubber Study Group on Rubber and the Environment, Glasgow, UK; 2002. pp. 34-78.

[13] BFIDC. 1995. Revised Project Proposal for Second Rubber Development Project, Tangail and Sherpur Region, Planning and Development Division, Government of the Peoples' Republic of Bangladesh, $131 \mathrm{pp}$.

[14] BFIDC. 2015. Garden and Industries, Bangladesh Forest Industries Development Corporation. (BFIDC) Government of the People's Republic of Bangladesh. http://www.bfidc.gov.bd/site/page/fa44e5778362-4cbd-ac31b0fd58445537/-Accessed on 26 December 2019.

[15] Hossain MK. 2016. Plantation forestry- paradign to meet the demand of the forestry resources in Bangladesh. In: Monoculture FarmingGlobal Perspectives, Ecological Impact and Benefits/Drawbacks (T.K. Nath and Patrick O'Reily, Eds.), New York, Nova Publishers. Edition: 1st, Chapter: 3.

[16] A.K.M. Abul Kalam Azad, Md. Najmus Sayadat Pitol and Yonosuke Hara. "The role of Rubber (Hevea brasiliensis) plantation in carbon storage at Bandarbans Hill Tract, Bangladesh”, 2021. International Journal of Current Research, 13, (05), 17373-17377. DOI:https://doi.org/10.24941/ijcr.41365.05.2021.

[17] Pitol MN, Khan MZ, Khatun R. 2019. Assessment of Total Carbon Stock in Swietenia macrophylla Woodlot at Jhenaidah District in Bangladesh. Asian Journal of Research in Agriculture and Forestry, 2(3), 1-10. https://doi.org/10.9734/AJRAF/2018/46922.

[18] Akhter S, Rahman MS, Biswas MA, Nath SC. 2013. Suitability of rubber (Hevea brasiliensis) seed meal as poultry feed. Proceedings of the first International Conference on Bio-resources and stress management held at Science City. Kolkata.

[19] Sattar MK. 1991, February 14. Physical mechanical and seasonal properties of Bangladeshi rubber wood (hevea brasiliensis). Timber Physics Series, 8(13), pp. 8-12.

[20] Sattar, M. 1995. Utilization of rubber wood: A Timber from the nonconventional source. Bangladesh Journal of Forest Science, 24 (1), 16.

[21] Das SA. 1995. Chemical components and water repellent property of rubber wood (Hebea brasiliensis) from Bangladesh. Bangladesh Journal of Forest Science, 24 (1), 58-61.

[22] ADB. 1997. Re-evaluation of the rubber rehabilitation expansion project in Bangladesh. Asian Development Bank.

[23] BBS. 2011. Bangladesh Census. Dhaka: Bangladesh Bureau of Statistics, Government of the Peoples Republic of Bangladesh.

[24] Rodrigoa, V. S. (2005). The growth and yield of rubber at maturity is improved by intercropping with banana during the early stage of rubber cultivation. Field Crops Research, 23-33.

[25] Pathiratna, L. S. (2006). Management of intercrops under rubber: Implications of competition and possibilities for improvement. Bulletin of the Rubber Research Institute of Sri Lanka, 47, pp. 8-16.

[26] Khan, N. A., \& Ahmed, F. U. (2002). Farming practice and sustainable development in Chittagong Hill Tracts (CHT). Government of Bangladesh and VFFP-IC Swiss Agency for Development and Cooperation.

[27] IRB. (2011). Annual Rubber Report. New Delhi: Indian Rubber Board.

[28] Therumthanam, A. M. (2014). Studies on pineapple (Ananas comosus) cultivation as an intercrop in rubber replant: Effects on soil microorganisms. Journal of Science and Technology, 4(2), 119-127.

[29] Nath, T.K., Inou, M. (2008). The upland settlement project of Bangladesh as a means of reducing land degradation and improving rural livelihoods. Small-scale Forestry, 7, 163-182.

[30] Azad AK, Pitol MNS, Rakkibu MG. 2020. Livelihood status of Sundarbans dependent people at Shymnagar Upazila of Satkhira, Bangladesh. Asian J For 5: 28-35. DOI: https://doi.org/10.13057/asianjfor/r050104.

[31] Dey, T., Kamruzzaman, M., Islam, M. A., Bachar, B. K. and Pitol,M. N. S. (2020). Attitudes of local people towards community based ecotourism in the Sundarbans. International Journal of Business, Management and Social Research, 09(02), 528-535. DOI:https://doi.org/10.24018/ejfood.2020.2.6.204.

[32] Islam A, Sharmin A, Biswas R, Dey T, Bachar BK et al. (2020) Utilization of Minor Forest Products of the Sundarbans in Bangladesh. Adv in Agri, Horti and Ento: AAHE-126. https://kosmospublishers.com/utilization-of-minor-forest-products-ofthe-sundarbans-in-bangladesh/.

[33] Nurunnahar, Pitol, M. N. S., \& Sharmin, A. (2020). Status and Prospects of Agroforestry at Kaligonj Upazila in Satkhira District. European Journal of Agriculture and Food Sciences, 2(6). https://doi.org/10.24018/ejfood.2020.2.6.186.

[34] Ripon. S; Islam. M.A; Sharmin. A; Biswas. R; and Kumar. J; (2021) Sustainable Agroforestry Practice in Jessore District of Bangladesh. European Journal of Agriculture and Food Sciences, 3(1), 1-10. https://doi.org/10.24018/ejfood.2021.3.1.150.

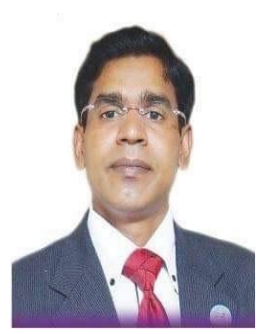

\section{Azad, AKM Abul Kalam}

Member of Bangladesh Civil Service Administration. His present position is Deputy Secretary working at Bangladesh Planning Commission. He completed his undergraduate BSc (Hons) in Forestry from Khulna University, later on he completed his MSc Forest. trop. from Technische Universitata Dresden, Germany under DAAD Fellowship. He has expertise on Forest Policy, Environment Policy, Forest Economics, Social Forestry, Forest Management, Timber, and non-timber forest resources utilization etc. He is presently doing his $\mathrm{PhD}$ in Public Policy at National Graduate Institute for Policy Study (GRIPS), Japan.

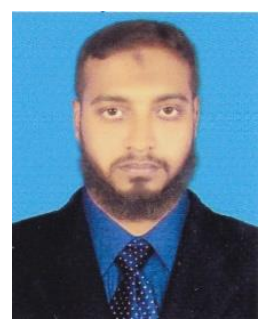

\section{Md. Najmus Sayadat Pitol}

Research Officer, Mangrove Silviculture Division, Bangladesh Forest Research Institute, Bangladesh. He completed his undergraduate BSc (Hons) in Forestry from Khulna University, later on he completed his MSc in Forest Management from Khulna University. He has expertise on Forest Management, Mangrove Ecology, Social Forestry, Timber and non-timber forest resources utilization and Forest Policy etc.

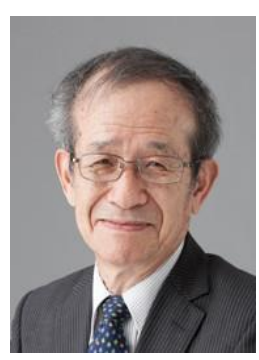

\section{Yonosuke Hara}

Adjunct Professor; Professor Emeritus.

Ph.D. (Agricultural Economics), University of Tokyo.

Education: B.A, Agriculture Economics, University of Tokyo, 1967. M.A, Agriculture Economics, University of Tokyo, 1969. Ph. D, Agriculture Economics, University of Tokyo, 1976.

Profession: Research Associate, Institute of Oriental Culture, University of Tokyo, 1972. Expert, United Nations Economic and Social Commission for Asia and the Pacific (UN/ESCAP), Bangkok, 1975-1977. Visiting Lecturer, University of Tokyo, 1978, Associate Professor, Institute of Oriental Culture, University of Tokyo, 1979. Professor, Institute of Oriental Culture, 1986. Director, Institute of Oriental Culture, 1998-2002 Professor, Graduate School of Interdisciplinary Information Studies / Institute of Oriental Culture, 2002-2006. Professor, GRIPS, 2006-2009 Senior Professor, GRIPS, 2009-2014, Academic Fellow, GRIPS, 2014present. 